\title{
Range Claypan Soil Improvement: Respons from Furrowing and Ripping in Northwester. South Dakota
}

\author{
E.M. WHITE, F.R. GARTNER, AND R. BUTTERFIELD
}

\begin{abstract}
Ripping and furrowing increased water infiltration and herbage production on some claypan range soils for 4 to 13 years. Infiltrating water in the ripped or furrowed soil zones redistributed extractable $\mathrm{Na}$ and salt toward the soils between the disturbed soil zones. This distribution of the water probably accelerates natural soil processes and will give long term increased forage production on nonsaline sodic soils.

Forage production is low in areas where the very slowly permeable, Na-dispersed claypan is near the surface. Most of the precipita-

Authors are professor of plant science (Soils), South Dakota State University, Brookings, 57007; and professor and research assistant of Animal Science, South Dakota State Univ. Res. and Ext. Center, Rapid City, 57701.

This report is S.D. Agr. Exp. Sta. Journal No. 1635.

Manuscript received May 24, 1979.
\end{abstract}

tion water runs off or evaporates from the surface so that litt left for forage production. In addition, the dispersed layer has $\mathrm{p}$ structure that restricts and limits root growth.

Mechanical treatments, such as furrowing (Branson et al. 1! Wight et al. 1978) and ripping (Hickey and Dortignac 1964; Al and Garcia 1972), create shallow depressions that store sur: water and/or rupture the dispersed claypan layer to increase $w$ infiltration. Lasting soil improvement occurs if the dispersed li cannot reform. Changes in soil chemical or physical proper caused by mechanical treatments are difficult to assess becaus the extreme variation in the Na-rich soils over small distar (White 1964). Thus, soil samples collected prior to treatment difficult to compare with those collected after an area has $b$ treated. Differences found in the soils could be attributed to initial sampling disturbance and not the mechanical treatment 
order to avoid this problem, soil samples were collected where the soil had been ripped on either side. Natural variation across the area and the effect of the treatment could be estimated from these samples.

\section{Study Areas and Treatments}

The study area locations are in northwestern South Dakota (Fig. 1). General soil properties, normal annual precipitation and temperatures, and the treatments are summarized in Table 1 and, if needed, elaborated upon in the following descriptions of the areas and the soil sampling locations.

Area 1 had vegetated areas with moderate amounts of western and thickspike wheatgrass (Agropyron smithii, nomenclature follows Beetle 1970), and $A$. dasystachyum blue grama (Bouteloua gracilis), scattered big sagebrush (Artemisia tridentata) and Nuttall saltbush (Atriplex nuttalli), and patches of plains pricklypear (Opuntia polyacantha) which occurred sporadically between nearly barren small "slickspots." The area was contour furrowed with an Arcadia Model B furrower. This machine created furrows about $50 \mathrm{~cm}$ wide and $15 \mathrm{~cm}$ deep with a $150-\mathrm{cm}$ spacing. The furrower was pulled behind a ripper which ripped the soil to a depth of $50 \mathrm{~cm}$.

The furrowed pasture was not grazed by livestock for three growing seasons following treatment and was moderately used by cattle and sheep in the spring and fall since that time. A permanent exclosure containing both furrowed and untreated claypan was crected soon after treatment.

Soil samples were taken inside the permanent exclosure. Soil profiles were samples from: (1) the first furrow at the edge of the plot beside or in a slickspot, (2) the adjacent ridge, (3) the next furrow, and (4) the second ridge.

Area 2 is on a high stream terrace that has not been flooded for many centuries. Western wheatgrass was the dominant species with an understory of blue grama and buffalograss (Buchloe dacty-

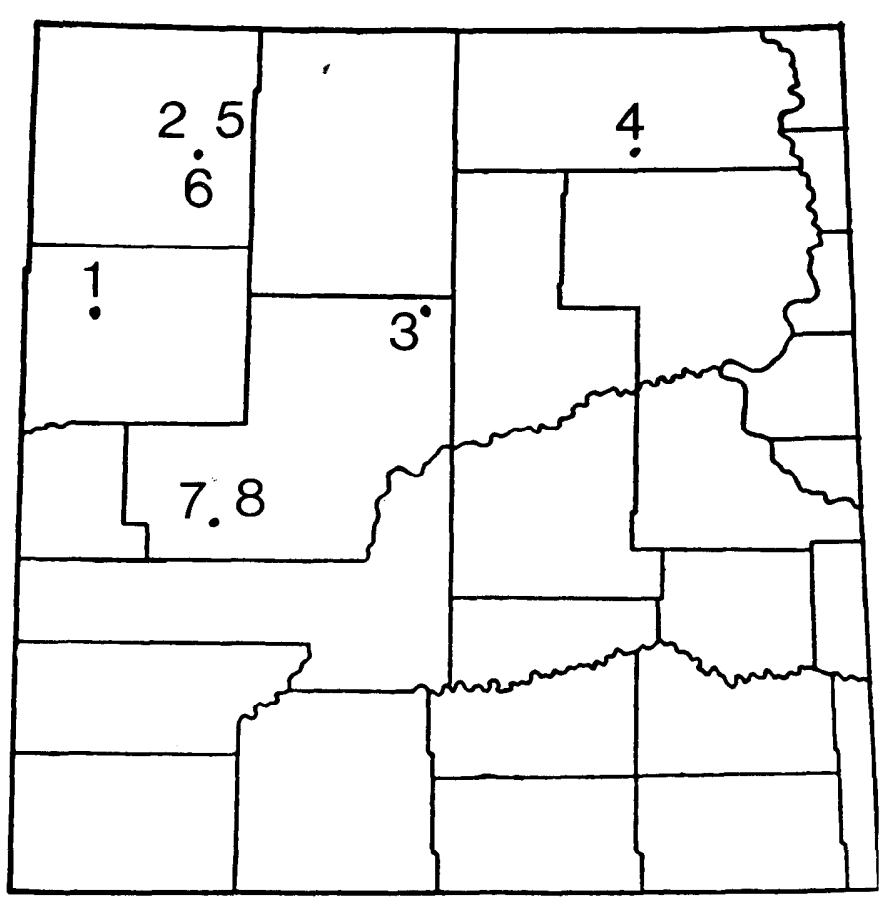

Fig. 1. Location of study areas 1, 2, 3, 4, 5, 6, 7, and 8 in western South Dakota.

loides) and scattered silver sagebrush (Artemisia cana) plants. This area was used as a winter pasture for cattle. Little or no growing season grazing use occurred most years. The soil profiles sampling sequence was (1) midway between two ripped zones, (2) from the ripped zone, and (3) midway across to the next ripped zone.

Table 1. Description of soils and mechanical treatments at each study site.

\begin{tabular}{|c|c|c|c|c|c|c|}
\hline \multirow{2}{*}{\multicolumn{2}{|c|}{ Research }} & \multirow{3}{*}{$\begin{array}{l}\text { Pre-treatment soil description } \\
\text { Normal annual precipitation } \\
\text { temperature }(1941-70)\end{array}$} & \multicolumn{4}{|c|}{ Treatments } \\
\hline & & & \multirow{2}{*}{$\begin{array}{l}\text { Implement } \\
\text { and } \\
\text { orientation }^{1}\end{array}$} & \multirow{2}{*}{$\begin{array}{l}\text { Depth } \\
(\mathrm{cm})\end{array}$} & \multirow{2}{*}{$\begin{array}{l}\text { Spacing } \\
(\mathrm{m})\end{array}$} & \multirow[b]{2}{*}{ Date } \\
\hline Ranch & Area & & & & & \\
\hline Crago & 1 & $\begin{array}{l}\text { Level claypan formed from Pierre shalc; } \\
\text { barren slickspots numerous; } 36 \mathrm{~cm}, 6^{\circ} \mathrm{C} \text {. }\end{array}$ & $\begin{array}{l}\text { Furrower } \\
\quad \mathrm{C}\end{array}$ & $25-40$ & 1.5 & Fall 1965 \\
\hline Antelope & 2 & $\begin{array}{l}\text { Nearly level claypan formed from clay or } \\
\text { silty clay alluvium at base of colluvial-alluvial } \\
\text { slope; few barren slickspots; } 36 \mathrm{~cm}, 6^{\circ} \mathrm{C} \text {. }\end{array}$ & $\underset{\mathrm{C}}{\text { Ripper }}$ & $38--51$ & 0.6 & May 1973 \\
\hline Antelope & 6 & $\begin{array}{l}\text { Gently sloping claypan formed from very fine } \\
\text { sandstone or siltstone; barren slickspots inter- } \\
\text { spersed with hummocks of wind deposited } \\
\text { material; } 36 \mathrm{~cm}, 6^{\circ} \mathrm{C} \text {. }\end{array}$ & $\begin{array}{l}\text { Ripper } \\
\text { UD }\end{array}$ & $38-50$ & 1.2 & May 1973 \\
\hline Antelope & 5 & $\begin{array}{l}\text { Nearly level clay soils formed from alluvium } \\
\text { and a shale of Hell Creek formation on lower } \\
\text { part of long, southerly slope; } 36 \mathrm{~cm}, 6^{\circ} \mathrm{C} \text {. }\end{array}$ & $\underset{\text { A }}{\text { Ripper }}$ & $25-35$ & $0.6-1.0$ & Fall 1960 \\
\hline Kammerer & 7 & $\begin{array}{l}\text { Nearly level claypan on lower colluvial slope } \\
\text { leading from Pierre shale; slickspots few; } 43 \\
\mathrm{~cm}, 8^{\circ} \mathrm{C} \text {. }\end{array}$ & $\underset{\text { C }}{\text { Ripper }}$ & $38-50$ & 1.2 & May 1973 \\
\hline Kammerer & 8 & $\begin{array}{l}\text { Gently sloping clay soil formed from Pierre } \\
\text { shale; slickspots common; } 43 \mathrm{~cm}, 8^{\circ} \mathrm{C} \text {. }\end{array}$ & $\underset{\mathrm{C}}{\text { Ripper }}$ & $38-50$ & 0.6 & May 1973 \\
\hline Drageset & 4 & $\begin{array}{l}\text { Gently sloping, weakly developed claypay } \\
\text { formed from fine-grained sandstone or silt- } \\
\text { stone of Hell Creek formation; slickspots } \\
\text { common; } 44 \mathrm{~cm}, 6^{\circ} \mathrm{C} \text {. }\end{array}$ & $\begin{array}{l}\text { Ripper } \\
\text { UD }\end{array}$ & $38-50$ & 1.2 & May 1973 \\
\hline Fischbach & 3 & $\begin{array}{l}\text { Gently sloping claypan formed from very fine } \\
\text { grained sandstone or coarse siltstone of Hell } \\
\text { Creek formation; slickspots few; } 42 \mathrm{~cm}, 8^{\circ} \mathrm{C} \text {. }\end{array}$ & $\underset{\text { C }}{\text { Ripper }}$ & $30-40$ & 0.4 & May 1973 \\
\hline
\end{tabular}

IC-on contour; UD-up and down slope; A-at angle to slope. 
Area 3 had blue grama and buffalograss as the most abundant grasses with some western wheatgrass and needle and thread (Stipa comata). Plains pricklypear occurs in patches where vegetation was sparse at the edges of barren slickspots. The area was deferred from growing season grazing use for one year subsequent to treatment. Since that time it has received heavy early spring use by cattle. The profiles sampled were: (1) at the edge of the ripping in a barren slickspot $20 \mathrm{~cm}$ from the first ripped zone, (2) the first ripped zone, (3) $20 \mathrm{~cm}$ toward the second ripped zone, (4) the second ripped area, and (5) $20 \mathrm{~cm}$ toward the next ripped zone. Soil profiles 2 through 5 had the surface layer of grass sod.

Area 4 is in a small eroded badlands basin which accumulates runoff water from a steep slope beside the area. Blue grama was the dominant grass species and occurred in patches surrounded by barren areas. Western wheatgrass, sand dropseed (Sporobolus cryptandrus), and silver sagebrush were present. The area had been fenced from grazing since treatment. The profiles sampled were: (1) $25 \mathrm{~cm}$ from the first ripped zone, (2) the first ripped zone, and (3) 25 $\mathrm{cm}$ toward the second ripped zone.

Area 5 had nearly a pure stand of western wheatgrass that formed a discontinous canopy over the otherwise barren soil. This area received moderate early spring grazing use for two growing seasons after treatment and has received moderate late spring-early summer cattle use since that time.

The area is less than a mile from Areas 2 and 6. One profile was collected to determine if some soil property reduced the beneficial effect of the treatment.

Area 6 had blue grama, sand dropseed, and needle and thread as the dominant grasses with scattered patches of plains pricklypear and brittle pricklypear (Opuntia fragilis). The area had been fenced from grazing since treatment. One profile was collected from the area.

Area 7 may have been cultivated for a few seasons in the past and had very sparse vegetation. Western wheatgrass had been seeded at the time of ripping and plants were concentrated in the ripper teeth channel at time of sampling. The area received no livestock grazing use subsequent to treatment. The soil profiles collected, aligncd across the ripping, were: (1) $60 \mathrm{~cm}$ from the first ripped zone, (2) the ripped zone, and (3) $60 \mathrm{~cm}$ towards the next ripped zone.

Area 8 is located about $75 \mathrm{~m}$ upslope from Area 7. Pierre shale was the main parent material. Individual western wheatgrass plants were vigorous but bare soil occurred between the plants. The soil profiles sampled were: (1) midway between the two ripped zones at the edge of the treated area, (2) the edge of the ripped zone, and (3) $30 \mathrm{~cm}$ upslope from the edge of the ripped plot.

\section{Methods}

\section{Soil Sampling Procedure}

Soils were sampled from mechanically treated areas in 1977 at previously unsampled locations. At least three soil profiles were sampled from areas where treatment had caused visible improvement in the vegetation. In these areas, profiles were collected from the soil disturbed by the treatment and on either side midway to the next disturbed soil profile. Horizontal gradational changes in the soil before the mechanical disturbance can be detected with this procedure so that changes from the treatment can be estimated.

\section{Laboratory Methods}

Standard laboratory methods (Jackson 1958) used were briefly: extractable cations- $\mathrm{NH}_{4} \mathrm{OAc}$ and flame photometry; organic matter-Walkley-Black wet oxidation; total N-Kjeldahl; Cation Exchange Capacity (C.E.C.) $-\mathrm{NaOAc}-\mathrm{NH}_{4} \mathrm{OAc}$ and flame photometry; and $\mathrm{pH}-1: 1$ soil:water and glass electrode. Water content and electrical conductivity were determined according to Richards (1954).

\section{Vegetation Sampling}

Vegetation response to mechanical trcatment was measured by either plant height or herbage production. Either leaf lengths or seed head heights of a dominant grass species were measured on both treated and untreated soil in Areas 2, 3, 7, and 8. Herbage productions were sampled on Areas 1, 7, and 8 by clipping to ground level and oven drying standing crop vegetation. Current year's growth was separated from old growth by meaningful species groups in the field. At Area 1, samples were clipped from ten 31 $\times 293 \mathrm{~cm}(1 \times 4.8 \mathrm{ft})$ plots randomly located within a temporary exclosure on both treated and untreated soil in early August, 1978. At Areas 7 and 8 the clipping was done within stratified units, based on soil and vegetation patterns (Waller et al. 1978). Stratification resulted in divisions with the following pretreatment vegetation characteristics: (1) areas supporting a dense stand of western wheatgrass; (2) areas almost devoid of western wheatgrass (slick spots), and (3) intermediate areas supporting a sparse stand of western wheatgrass. In strata 1 and 3, 24 plots measuring $31 \times 146$ $\mathrm{cm}(1 \times 4.8 \mathrm{ft})$ were clipped on the treated soil and the same number on untreated soil. In strata 2, 16 plots were clipped on both treated and untreated soil.

Analysis of variance was used to determine if the vegetation parameters varied significantly between treated and untreated areas. Since none of the sites had true replication of the mechanical treatments, individual samples (a clipped plot or measurement of plant height) or group of samples were treated as replications in the analyses. This approach results in a valid test of the difference between the treated and untreated area, but cannot be used to attribute this difference to the effects of the treatment. Statements of significance should be interpreted with this knowledge.

\section{Results and Discussion}

\section{Vegetation Response to Ripping}

Leaf length and seed head height of grasses at Areas 2, 3, 7, and 8 were significantly greater for the treated than the untreated plots (Table 2). Total herbage production was greater on the mechani-

Table 2. Average leaf lengths and seedhead heights of selected grasses on treated and untreated plots at Areas 2, 3, 7, and 8 in fall, 1977.

\begin{tabular}{cccc}
\hline \hline & \multicolumn{2}{c}{ Treatment } & \multirow{2}{*}{$\mathrm{N}^{1}$} \\
\cline { 2 - 3 } Area & None & Ripped & \\
\hline \multicolumn{4}{c}{ Average leaf length of western wheatgrass $(\mathrm{cm})^{2}$} \\
7 & 18.3 & $27.1^{* * 3}$ & 100 \\
8 & 14.8 & $20.0^{* *}$ & 100 \\
& 20.6 & $25.9^{* *}$ & 100 \\
3 & Average seed height, blue grama (cm) \\
& 16.6 & $28.8^{* *}$ & 80 \\
\hline
\end{tabular}

'N-- number of plants measurcd.

${ }^{2}$ Measured from soil surface to tip of longest leaf.

${ }^{3}$ Significantly different at $p=0.01$.

cally treated plots than the untreated plots on Areas 1, 7, and 8 (Table 3 and 4). Most of this increase was due to western wheatgrass production on Areas 7 and 8 or western and thickspike wheatgrass production on Area 1. The exception to this trend was in the "Negligible wheatgrass" strata on Areas 7 and 8 , where the annual grass component provided the largest increase to herbage production. Sweetclover (Melilotus officinalis) production was higher on ripped than the untreated plot for all strata at Areas 7 and 8 . At Area 1 sweetclover yield was not signficantly higher on the furrowed than the untreated plots. Sweetclover was seeded on part of the ripped treatment at Areas 7 and 8 soon after the ripping was completed in the spring of 1973 . The sweetclover had spread, more or less uniformly, over the entire ripped area by 1977 , but was still sparse on the adjacent untreated claypan. At Area 1 sweetclover was not seeded on the study site, but was seeded as close as $0.2 \mathrm{~km}(1 / 8 \mathrm{mile})$ from the study site.

Other vegetation changes were not consistent between the two sites. "Shortgrasses" (buffalograss and blue grama) produced less herbage on the ripped than on the untreated plot in the "Dense wheatgrass" strata of Areas 7 and 8 . However, the shortgrass component produced more on the furrowed than the untreated 
Table 3. Herbage production $(\mathrm{kg} / \mathrm{ha}$ ) on furrowed and untreated range at Area 1 in 1978.

\begin{tabular}{lcc}
\hline & \multicolumn{2}{c}{ Mechanical treatment } \\
\cline { 2 - 3 } Species group 1 & None & Furrowed \\
\hline Wheatgrass & 206 & $885^{* * 2}$ \\
Shrub & 132 & 68 \\
Forb & 28 & 88 \\
Shortgrass & 16 & $104^{* *}$ \\
Other grasses & 11 & $140^{* *}$ \\
Sweet clover & 4 & 80 \\
\multicolumn{1}{c}{ Total yield } & -137 & $-1365^{* *}$ \\
\hline
\end{tabular}

'Wheatgrass-Agropyron smithii and A. dasystachyum.

Shrubs-Artemisia tridentata. Atriplex nuttallii, and Xanthocephalum sarothrae.

Forbs-Vicia americana, Lepidium densiflorum, Lamatium sp., Plantago spinulosa, and Polygonum sp.

Shortgrasses-Buchloe dactyloides and Bouteloua gracilis.

Other grasses-Poa secunda, Koeleria cristata, Sporobolus cryptandrus, and Sche. donnardus paniculatus.

Sweetclover-Melilotus officinalis.

2** Furrowed and untreated plots had significantly different $(p<0.01)$ yields.

plot at Area 1. The "other grass" component was not affected by ripping at Areas 7 and 8, but was more productive on the furrowed areas than the untreated claypan at Area 1.

These inconsistencies probably are due to the difference in grazing treatment or soils between the two sites. Mechanical disturbance would be expected to favor the rhizomatous wheatgrass over the "shortgrass" and "other grass" components as seen at Areas 7 and 8 . Grazing during the growing season at Area 1 probably reduced the vigor and competitive advantage of the wheatgrass somewhat, allowing the other two vegetation components to exploit a portion of the increase in site potential.

\section{Effect of Ripping on the Soils}

The effect of ripping or furrowing on water infiltration should be evaluated by measuring soil water contents after rains which occurred when the soil was relatively dry. All the soils studied had moisture contents near the wilting point earlier in the summer. The study areas had received rain a few days before the soils were sampled except Areas 7 and 8.

Soils in the furrow bottoms at Area 1 had more water than the adjacent ridges (Fig. 2). The Arca 1-Profile 1 (henceforth 1P1) had the ridge on one side while IP3 was bounded by a ridge on both sides so that more water could run in to give it a higher water content. In addition $1 \mathrm{PI}$ and $1 \mathrm{P} 2$ were exposed more to the dry south winds than $1 \mathrm{P} 3$ and 1P4. Profile 1P4 also had a higher saturation water content (Fig. 3), extractable Na (Fig. 4), and
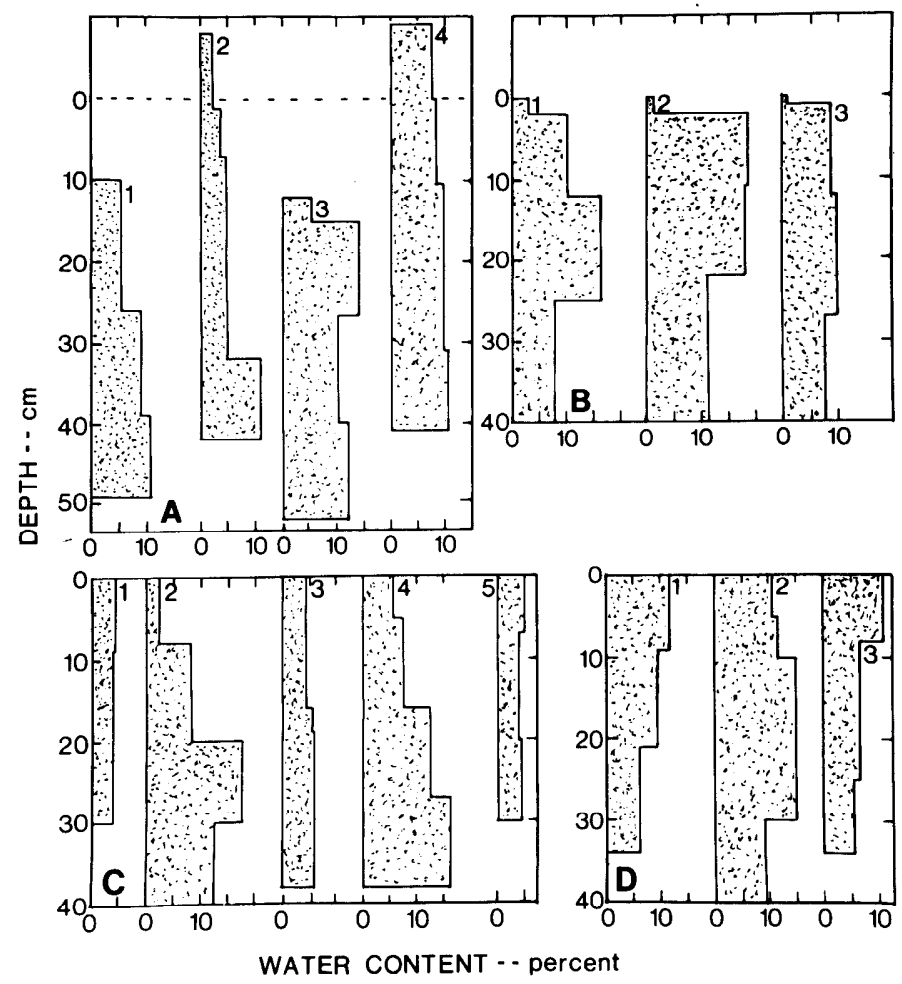

Fig. 2. Water contents of the soils when sampled in Areas 1,2, 3, and 4(A, $B, C$, and $D$ respectively).

electrical conductivity (Fig. 5). The water retaining capacity probably was higher in 1P4 at the wilting point than 1P2 because of osmotic effects.

Soils collected from the ripped zones of Area 2 (2P2), Area 3 (3P2, 3P4), and Area 4 (4P2) contained more soil water (Fig. 2) than the comparable adjacent soils. Soils at Area 2 increased in the saturation water content from $\mathbf{P} 1$ through $\mathbf{P} 3$ (Fig. 3) which indicated the soils were not uniform across the area. However $2 \mathrm{P} 2$ had a higher water content at sampling than either $2 \mathrm{P} 1$ or $2 \mathrm{P} 3$ so the increase was not related to this gradient change. Area 3 also had this gradational change in saturation water content but the differences in water content at sampling do not appear to be related to soil differences (Fig. 2-C). The water contents at the time of sampling would have been higher in the disturbed zones if a very narrow band of soil could have been collected in the disturbed zone. However, this was not possible with the sample technique

Table 4. Herbage production $\mathrm{kg} \cdot \mathrm{ha}$ in 1977 from ripped and untreated plots in range containing Areas 7 and 8.

\begin{tabular}{|c|c|c|c|c|c|c|}
\hline \multirow[b]{4}{*}{ Species group ${ }^{1}$} & \multicolumn{6}{|c|}{ Initial western wheatgrass stand } \\
\hline & \multicolumn{2}{|c|}{ Dense } & \multicolumn{2}{|c|}{ Sparse } & \multicolumn{2}{|c|}{ Negligible } \\
\hline & \multicolumn{6}{|c|}{ Mechanical Treatment } \\
\hline & None & Ripped & None & Ripped & None & Ripped \\
\hline Wheatgrass & 799 & $1170 * *$ & 172 & $498 * *$ & 4 & $74^{*}$ \\
\hline Forb & 15 & 13 & 82 & $8^{* *}$ & 206 & $13 * *$ \\
\hline Shrub & 64 & 77 & 68 & 121 & 242 & $304^{*}$ \\
\hline Sweet clover & 28 & $92 * *$ & $t^{4}$ & $91^{* *}$ & 1 & $99 * *$ \\
\hline Short grass & 21 & $0 \S^{3}$ & 1 & 7 & 1 & 1 \\
\hline Other grass & 110 & $110^{\circ}$ & 62 & 67 & 83 & 66 \\
\hline Annual grass & 28 & $119 * *$ & 1 & $54 * *$ & $\mathrm{t}$ & $395^{*}$ \\
\hline Cactus & 6 & 47 & 77 & 26 & 129 & $t$ \\
\hline Total yield ${ }^{2}$ & 1065 & $1581^{* *}$ & 386 & $846^{* *}$ & 537 & $952^{* *}$ \\
\hline
\end{tabular}

IWheatgrass-Agropyron smithii; Forbs-Plantago spinulosa, Kochia scoparia, Atriplex sp., and Lepidium sp.; Shrubs-Artemisia cana and Gutierrezia sarothrae; Shortgrass-Buchloe dactyloides and Bouteloua gracilis; Other grasses Poa secunda, P. junifolia, Sporobolus cryptandrus, Sitanion hystrix, Distichlis spicata stricta, and Schedonnardus paniculatas; Annual grasses-Bromus japonicus and Hordeum pusillum; Cactus-Opuntia fragilis and O. polycanthus.

2Opuntia not included in total yield.

Significance levels are: $\&, P=0.10 ;{ }^{*}, p=0.05 ;{ }^{* *}, p p=0.01$.

${ }^{4} \mathrm{t}=$ trace. 

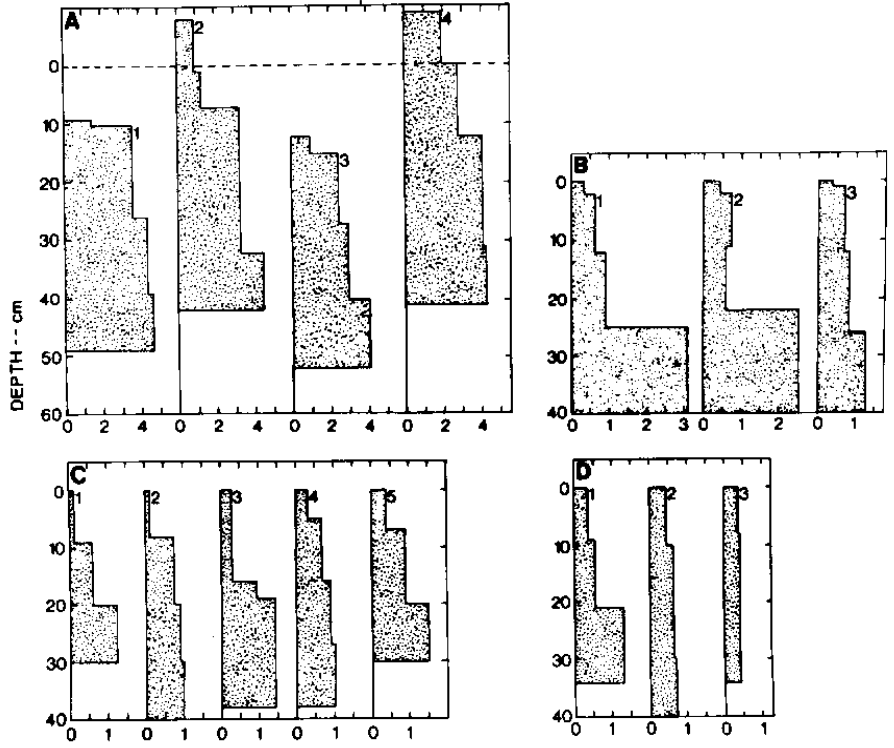

MICROMHOS $/ \mathrm{cm} \times 10^{3}$

Fig. 3. Saturation water contents of the soils from A reas $1,2,3$, and 4 ( $A$, $B, C$, and $D$ respetively).

used. This soil band tended to be very moist and plastic, particularly at Areas 2, 3, and 4.

The extractable $\mathrm{Na}$ includes the exchangeable $\mathrm{Na}$ and $\mathrm{Na}$ in salts. Dispersion is caused by the exchangeable $\mathrm{Na}$ while salts in sufficient concentration counteract dispersion. Na can cause dispersion if it remains as a major $>15 \%$ ) exchangeable cation after $\mathrm{Na}$ salts are leached. Area 1 showed differences in the extractable
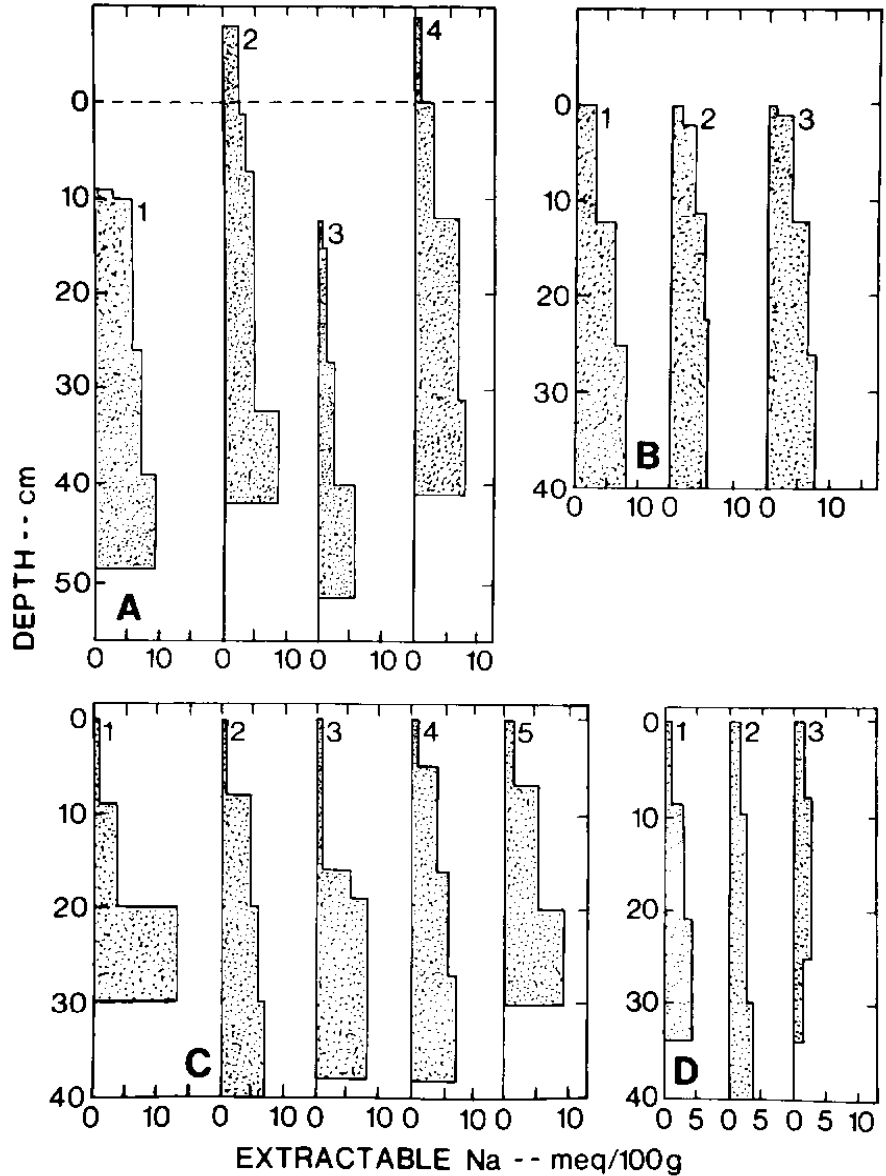

Fig. 4. Extractable sodium content in the soils from Areas 1, 2, 3, and 4 (A, $B, C$, and $D$ respectively). sodium contents of the soils (Fig. 4), which is a natural variation of most claypan areas. Soil $1 \mathrm{Pl}$ had the most extractable $\mathrm{Na}$ and the amount decreased through IP3 and then increased in 1P4. Soil IP1 was at the edge of a barren slickspot. Area 2 also had a gradational change in the extractable $\mathrm{Na}$ contents, although it is possible that an $\mathrm{Na}$ moved laterally from $2 \mathrm{P} 2$ to $2 \mathrm{P} 1$ and $2 \mathrm{P} 3$. However, this lateral movement was not observable in the salt content, as measured by electrical conductivity (Fig. 5-B), because it would have been masked by soil changes across the area. However, lateral movement of salt seems likely at Area 3 since both extractable $\mathrm{Na}$ contents and the electrical conductivities of the profiles disturbed by ripping $3 \mathrm{P} 2$ and $3 \mathrm{P} 4$ were lower than for the adjacent soils (Fig. 5-C). This movement occurs with trickle irrigation (Bresler 1975) where water applied locally diffuses downward and laterally and transports salt into the adjacent soil.

Areas 1,2 , and 4 demonstrate a salinity gradient across the areas, which is typical for soils affected by Na dispersion. However, some of the electrical conductivity was not from $\mathrm{Na}$ but was from gypsum, which is moderately soluble salt. The relatively high electrical conductivities of soils in Areas 1 and 2 (Fig. 5) and for 5, 6,7 , or 8 (Table 5 ) probably were caused by gypsum originally in the parent material. The electrical conductivity changes across Area 8 were possibly related to the extractable $\mathrm{Na}$ contents (Table 5 ) in the form of soluble $\mathrm{Na}$ salts. Soil $8 \mathrm{P3}$ was located on the upslope side of Area 8. At this location, seep water probably carried salt into the subsoil as it flowed downslope over the Pierre shale substratum resulting in a buildup of salts in this profile.

Ripping or furrowing apparently has little or no effect on the organic matter and total $\mathrm{N}$ contents or the $\mathrm{pH}$ of the soils across the treated areas (Tables 5 and 6). The higher organic matter and total $\mathrm{N}$ contents in the furrow surface layers in comparison to the ridges in Area 1 is caused by the deposition of organic-rich sediment from the ridges and possibly the growth of algae and lichens.

\section{Long-term Effect of Ripping or Furrowing on Claypan soils and Range Production}

Range production is greater today on some claypan soils in western South Dakota that were ripped or contour furrowed 10 to 20 years ago. Areas where mechancial treatment has been most successful are contour tilled (ripped) where the disturbed soil intercepts runoff water. In order for treatments to be successful, the soils need to be in the process of losing $\mathrm{Na}$ by natural leaching. Water entry into the soil area at periodic locations increases leaching at these locations and decreases it at others. This leaching
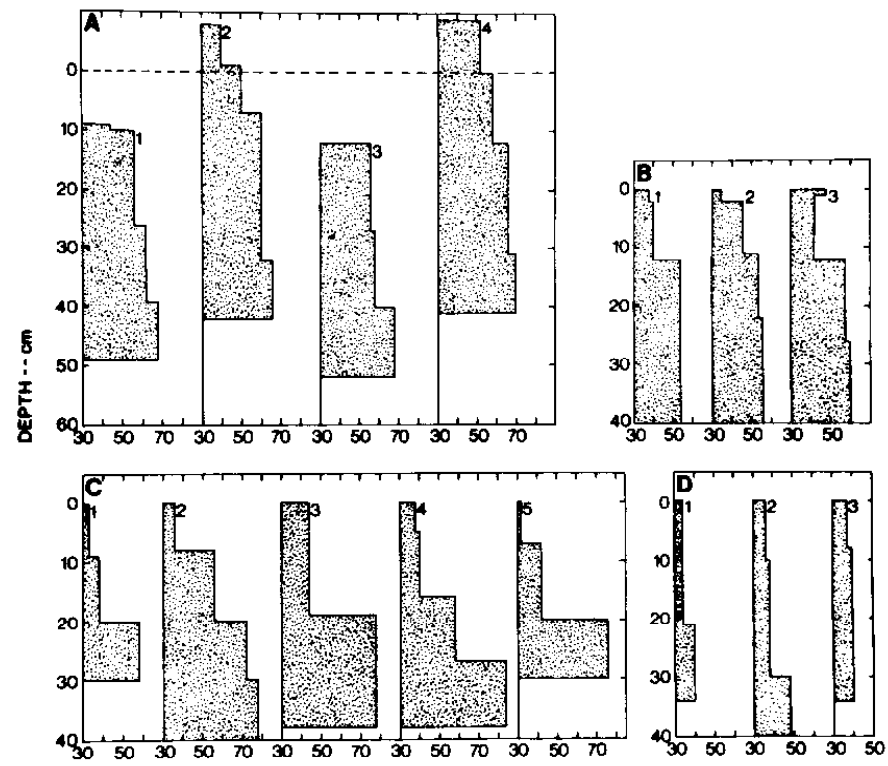

SATURATION WATER ... percent

Fig. 5. Electrical conductivity of the saturated pastes of soil from Areas $I$, 2,3 , and $4(A, B, C$, and $D$ respectively). 
Table 5. Laboratory properties of soils from Areas 5, 6, 7, and 8.

\begin{tabular}{|c|c|c|c|c|c|c|c|c|c|}
\hline \multirow[b]{2}{*}{ Profile } & \multirow[b]{2}{*}{$\begin{array}{l}\text { Depth } \\
\text { (cm) }\end{array}$} & \multirow[b]{2}{*}{ Horizon } & \multirow[b]{2}{*}{$\mathrm{pH}$} & \multirow{2}{*}{$\begin{array}{c}\text { Organic } \\
\text { Matter } \\
(\%)\end{array}$} & \multirow{2}{*}{$\begin{array}{c}\text { Total } \\
\mathbf{N} \\
(\%)\end{array}$} & \multicolumn{2}{|c|}{ Water Content } & \multirow{2}{*}{$\begin{array}{c}\text { Extractable } \\
\mathrm{Na} \\
(\% \text { of } \mathrm{CEC})\end{array}$} & \multirow{2}{*}{$\begin{array}{c}\text { Conductivity } \\
\text { micro } \\
\text { mohs } / \mathrm{cm})\end{array}$} \\
\hline & & & & & & $\begin{array}{c}\text { Field } \\
(\%)\end{array}$ & $\begin{array}{c}\text { Saturation } \\
(\%)\end{array}$ & & \\
\hline 1 & $\begin{array}{c}\text { Area } 5 \\
0-1 \\
1-11 \\
11-22 \\
22-31 \\
31-40\end{array}$ & $\begin{array}{l}\text { A } \\
\text { B21 } \\
\text { B22 } \\
\text { B3ca } \\
\text { C }\end{array}$ & $\begin{array}{l}6.7 \\
7.9 \\
8.6 \\
8.3 \\
8.1\end{array}$ & $\begin{array}{l}3.10 \\
2.44 \\
2.53 \\
1.76 \\
1.76\end{array}$ & $\begin{array}{l}.118 \\
.108 \\
.090 \\
.088 \\
.076\end{array}$ & $\begin{array}{r}.2 \\
6.2 \\
7.0 \\
6.4 \\
6.0\end{array}$ & $\begin{array}{l}34 \\
46 \\
52 \\
58 \\
52\end{array}$ & $\begin{array}{r}5 \\
8 \\
12 \\
15 \\
17\end{array}$ & $\begin{array}{r}260 \\
740 \\
1260 \\
2400 \\
3500\end{array}$ \\
\hline 1 & $\begin{array}{c}\text { Area } 6 \\
0-1 \\
1-10 \\
10-20 \\
20-30\end{array}$ & $\begin{array}{l}\text { A } \\
\text { B2 } \\
\text { B2ca } \\
\text { B3 }\end{array}$ & $\begin{array}{l}8.8 \\
9.0 \\
8.2 \\
8.2\end{array}$ & $\begin{array}{l}1.08 \\
1.52 \\
1.56 \\
1.63\end{array}$ & $\begin{array}{l}.053 \\
.038 \\
.050 \\
.041\end{array}$ & $\begin{array}{c}\text { air dry } \\
4.4 \\
13.6 \\
6.7\end{array}$ & $\begin{array}{l}32 \\
42 \\
40 \\
54\end{array}$ & $\begin{array}{l}16 \\
35 \\
53 \\
52\end{array}$ & $\begin{array}{r}550 \\
1770 \\
3400 \\
4300\end{array}$ \\
\hline 1 & $\begin{array}{c}\text { Area } 7 \\
0-5 \\
5-2 \\
12-19 \\
19-32 \\
32-40\end{array}$ & $\begin{array}{l}\text { A } \\
\text { B1 } \\
\text { B2 } \\
\text { B31sa } \\
\text { B32sa ca }\end{array}$ & $\begin{array}{l}7.7 \\
8.2 \\
8.2 \\
8.2 \\
8.5\end{array}$ & $\begin{array}{r}3.06 \\
2.11 \\
2.20 \\
1.10 \\
.99\end{array}$ & $\begin{array}{l}.113 \\
.107 \\
.095 \\
.081 \\
.066\end{array}$ & $\begin{array}{l}1.2 \\
4.2 \\
5.8 \\
6.7 \\
7.8\end{array}$ & $\begin{array}{l}38 \\
48 \\
60 \\
50 \\
56\end{array}$ & $\begin{array}{l}13 \\
20 \\
28 \\
37 \\
42\end{array}$ & $\begin{array}{r}720 \\
1480 \\
3800 \\
5100 \\
6300\end{array}$ \\
\hline 2 & $\begin{array}{c}0-5 \\
5-12 \\
12-30 \\
20-32 \\
32-40\end{array}$ & $\begin{array}{l}\text { A1 } \\
\text { B1 } \\
\text { B2 } \\
\text { B31sa } \\
\text { B32sa ca }\end{array}$ & $\begin{array}{l}8.5 \\
8.2 \\
7.9 \\
8.1 \\
8.1\end{array}$ & $\begin{array}{r}2.15 \\
1.80 \\
1.45 \\
1.31 \\
.90\end{array}$ & $\begin{array}{l}.103 \\
.097 \\
.087 \\
.077 \\
.062\end{array}$ & $\begin{array}{l}.1 \\
3.7 \\
5.3 \\
6.4 \\
8.3\end{array}$ & $\begin{array}{l}38 \\
56 \\
52 \\
50 \\
60\end{array}$ & $\begin{array}{l}16 \\
20 \\
28 \\
28 \\
40\end{array}$ & $\begin{array}{r}700 \\
1470 \\
3200 \\
4300 \\
5500\end{array}$ \\
\hline 3 & $\begin{array}{c}0-5 \\
5-12 \\
12-19 \\
19-32 \\
32-40\end{array}$ & $\begin{array}{l}\text { A } \\
\text { B1 } \\
\text { B2 } \\
\text { B31 sa } \\
\text { B32sa ca }\end{array}$ & $\begin{array}{l}7.8 \\
8.2 \\
8.1 \\
8.1 \\
8.3\end{array}$ & $\begin{array}{r}2.67 \\
2.09 \\
1.73 \\
1.12 \\
.94\end{array}$ & $\begin{array}{l}.109 \\
.099 \\
.087 \\
.074 \\
.068\end{array}$ & $\begin{array}{l}1.2 \\
4.1 \\
5.3 \\
6.8 \\
3.7\end{array}$ & $\begin{array}{l}34 \\
50 \\
56 \\
52 \\
52\end{array}$ & $\begin{array}{l}12 \\
23 \\
32 \\
45 \\
42\end{array}$ & $\begin{array}{r}780 \\
1420 \\
4100 \\
5700 \\
6300\end{array}$ \\
\hline 1 & $\begin{array}{c}\text { Area } 8 \\
0-5 \\
5-11 \\
11-27 \\
27-40\end{array}$ & $\begin{array}{l}\text { A1 } \\
\text { B1ca } \\
\text { B2sa ca } \\
\text { B3sa ca }\end{array}$ & $\begin{array}{l}8.4 \\
7.9 \\
7.8 \\
8.1\end{array}$ & $\begin{array}{r}1.84 \\
1.73 \\
.92 \\
.66\end{array}$ & $\begin{array}{l}.112 \\
.099 \\
.064 \\
.051\end{array}$ & $\begin{array}{r}3.5 \\
6.8 \\
8.6 \\
10.7\end{array}$ & $\begin{array}{l}50 \\
58 \\
50 \\
66\end{array}$ & $\begin{array}{l}18 \\
23 \\
25 \\
39\end{array}$ & $\begin{array}{l}2200 \\
3200 \\
3500 \\
5300\end{array}$ \\
\hline 2 & $\begin{array}{l}0-5 \\
5-11 \\
11-27 \\
27-40\end{array}$ & $\begin{array}{l}\text { A } \\
\text { B1ca } \\
\text { B2sa ca } \\
\text { B3sa ca }\end{array}$ & $\begin{array}{l}8.4 \\
7.9 \\
8.0 \\
8.2\end{array}$ & $\begin{array}{r}1.87 \\
1.25 \\
.48 \\
.39\end{array}$ & $\begin{array}{l}.118 \\
.081 \\
.059 \\
.053\end{array}$ & $\begin{array}{r}1.9 \\
6.0 \\
8.9 \\
12.9\end{array}$ & $\begin{array}{l}52 \\
50 \\
56 \\
74\end{array}$ & $\begin{array}{l}17 \\
19 \\
37 \\
57\end{array}$ & $\begin{array}{l}1370 \\
3200 \\
4500 \\
6500\end{array}$ \\
\hline 3 & $\begin{array}{c}0-5 \\
5-11 \\
11-27 \\
27-40\end{array}$ & $\begin{array}{l}\text { Al } \\
\text { Blca } \\
\text { B2sa ca } \\
\text { B3sa ca }\end{array}$ & $\begin{array}{l}8.2 \\
8.4 \\
8.2 \\
8.3\end{array}$ & $\begin{array}{r}2.46 \\
1.34 \\
.96 \\
.22\end{array}$ & $\begin{array}{l}.137 \\
.123 \\
.052 \\
.052\end{array}$ & $\begin{array}{r}3.6 \\
7.6 \\
7.0 \\
12.4\end{array}$ & $\begin{array}{l}56 \\
66 \\
60 \\
68\end{array}$ & $\begin{array}{l}21 \\
23 \\
41 \\
72\end{array}$ & $\begin{array}{l}1360 \\
1900 \\
5400 \\
8600\end{array}$ \\
\hline
\end{tabular}

pattern approximates the complex leaching and soil patterns that characterize undisturbed areas of claypan soils with slickspots. Thus furrowing and ripping accelerates natural processes.

If $\mathrm{Na}$ leaching from the soil had not been initiated naturally, the substratum and lower soil would have characteristics that would decrease the effectiveness of ripping or furrowing. Some very young soils, such as those in Area 4 where the parent materials have recently been exposed by erosion, had very weak surface and subsurface structure. Sodium leaching was minimal from these young soils even though lower layers were permeable enough to allow leaching. Because these weakly developed soils had very unstable surface structure, ripping could increase productivity for only a short time before the soil would "settle back" and reduce the permeability. A similar situation occurred in Area 6. However, the hummocky surface will trap sufficient water to cause increased infiltration in the ripped soil zones.

Weak surface soil structure in fine-textured soils, such as those at Area 5, will reduce the effective beneficial life of the ripping particularly if the ripping is shallow as in Area 5. In weakly developed clay soils, parallelpiped structure is common near the surface. This structure forms because masses of soil swell obliquely to the soil surface (White and Lewis 1969). This swelling would close and compact the opening left by ripping. For this reason, claypan soils that are weakly developed clay soils should be contour furrowed rather than contour ripped.

Grazing use following treatment may decrease treatment longevity if livestock trampling occurs. Excessive grazing use and trampling will reduce water storage in furrows and accelerate soil settling in ripper channels. These negative effects of grazing are most important immediately after treatment before plant growth stabilizes the furrows and ridges and a new soil cracking system, initiated by ripping, has become established.

Grazing also can decrease treatment longevity by reducing plant vigor. Vigorous plant growth associated with good range management increases the overall treatment effect and longevity. Proper management would insure stability of the new soil surface and soil structure, which in turn would promote water infiltration. Early spring grazing use immediately after treatment may have had a negative impact on the treatment at Area 5. However, Area 3 received one year of growing season deferment and heavy spring use since then, and the effects of ripping are still apparent on the soils and vegetation even though the range condition is currently 
Table 6. Organic matter and nitrogen contents, pHs, and cation exchange capacities of the soils from Areas $1,2,3$, and 4 .

\begin{tabular}{|c|c|c|c|c|c|c|c|c|c|c|c|c|c|}
\hline Profile & $\begin{array}{l}\text { Depth }{ }^{1} \\
(\mathrm{~cm})\end{array}$ & Horizon & $\mathrm{pH}$ & $\begin{array}{c}\text { Organic } \\
\text { Matter } \\
(\%)\end{array}$ & $\begin{array}{c}\text { Total N } \\
(\%)\end{array}$ & $\begin{array}{c}\text { CEC } \\
\mathrm{meq} / 100 \mathrm{~g}\end{array}$ & Profile & $\begin{array}{l}\text { Depth } \\
(\mathrm{cm})\end{array}$ & Horizon & $\mathrm{pH}$ & $\begin{array}{c}\text { Organic } \\
\text { Matter } \\
(\%)\end{array}$ & $\begin{array}{c}\text { Total N } \\
(\%)\end{array}$ & $\begin{array}{c}\text { CEC } \\
\mathrm{meq} / 100 \mathrm{~g}\end{array}$ \\
\hline \multicolumn{2}{|c|}{ Area 1} & & & & & & \multicolumn{2}{|c|}{ Area 3} & & & & & \\
\hline \multirow[t]{6}{*}{1} & $0-9$ & Removed & & & & & 1 & $0-9$ & $A 1-A 2$ & 6.6 & 1.41 & .095 & 10.0 \\
\hline & $9-10$ & $\mathrm{AB}$ & 7.0 & 3.02 & .126 & 26.3 & & $9-20$ & B21 & 7.7 & 1.31 & .079 & 17.4 \\
\hline & $10-26$ & B2 & 7.4 & 2.43 & .120 & 32.1 & & $20-30$ & B22 & 8.5 & 1.24 & .066 & 23.3 \\
\hline & $26-39$ & B2sa & 7.8 & 1.67 & .089 & 35.7 & & & & & & & \\
\hline & $39-49$ & B3 & 8.1 & 1.24 & .070 & 38.5 & 2 & $0-8$ & $\mathrm{~A} 1-\mathrm{A} 2$ & 6.5 & 1.76 & .094 & 10.2 \\
\hline & $(-18-1$ & & & & & & & $8-20$ & B21 & 8.2 & 1.32 & .078 & 20.8 \\
\hline \multirow[t]{5}{*}{2} & $(-) 8-1$ & $\mathrm{AC}$ & 7.6 & 2.48 & .126 & 26.8 & & $20-30$ & B22 & 8.6 & 1.05 & .065 & 23.9 \\
\hline & $1-7$ & B1-B2 & 7.7 & 2.55 & .131 & 30.9 & & $30-40$ & B3ca & 8.6 & .70 & .051 & 22.7 \\
\hline & $7-32$ & B2sa & 7.4 & 1.31 & .120 & 38.4 & & & Drea & & & & \\
\hline & $32-50$ & B3 & 7.8 & 1.44 & .077 & 39.9 & 3 & $0-16$ & $\mathrm{~A} 1-\mathrm{A} 2$ & 6.6 & 2.55 & .126 & 10.6 \\
\hline & & & & & & & & $16-19$ & B21 & 8.4 & 2.28 & .064 & 17.7 \\
\hline \multirow[t]{4}{*}{3} & $\begin{array}{r}0-12 \\
12-15\end{array}$ & $\begin{array}{l}\text { Removed } \\
\text { Al }\end{array}$ & 6.9 & 4.42 & .169 & 35.7 & & $19-38$ & $\mathrm{~B} 22$ & 8.4 & .71 & .056 & 24.4 \\
\hline & $15-27$ & $\mathrm{~B} 2$ & 7.1 & 1.73 & .127 & 39.1 & 4 & $0-5$ & A1-A2 & 6.7 & 2.53 & .132 & 11.6 \\
\hline & $27-40$ & B31sa & 7.4 & 1.30 & .060 & 38.3 & & $5-16$ & B21 & 8.1 & 1.36 & .075 & 17.0 \\
\hline & $40-52$ & B32sa & 7.6 & .96 & .064 & 43.2 & & $16-27$ & B22 & 8.6 & .66 & .069 & 22.3 \\
\hline \multirow[t]{4}{*}{4} & $(-) 8-0$ & $\mathrm{AC}$ & 7.1 & 1.48 & .105 & 36.2 & & $27-38$ & B3 & 8.6 & .62 & .041 & 23.7 \\
\hline & $0-12$ & B1-B2 & 7.1 & 1.98 & .119 & 35.1 & 5 & $0-7$ & A1-A2 & 7.2 & 2.84 & .112 & 9.9 \\
\hline & $12-31$ & B2sa & 7.5 & 1.29 & .081 & 40.6 & & $7-20$ & B21 & 8.3 & 1.92 & .093 & 16.0 \\
\hline & $31-41$ & B3sa & 7.7 & 1.31 & .068 & 41.6 & & $20-30$ & $\mathrm{~B} 22$ & 7.1 & 1.63 & .064 & 23.9 \\
\hline \multicolumn{2}{|c|}{ Area 2} & & & & & & \multicolumn{2}{|c|}{ Area 4} & & & & & \\
\hline \multirow[t]{4}{*}{1} & $0-2$ & Al & 6.6 & 5.30 & .196 & 17.2 & \multirow[t]{4}{*}{1} & $0-9$ & A & 6.7 & 2.37 & .097 & 16.5 \\
\hline & $2-12$ & B21 & 6.4 & 2.39 & .191 & 25.6 & & $9-21$ & B21 & 7.6 & 1.42 & .062 & 24.6 \\
\hline & $12-25$ & B22 & 8.6 & 1.44 & .115 & 32.1 & & $21-34$ & B3 & 8.3 & .79 & .049 & 21.0 \\
\hline & $25-40$ & B3 & 8.1 & 1.23 & .084 & 33.2 & & & & & & & \\
\hline \multirow[t]{4}{*}{2} & $0-2$ & A & 6.9 & 3.64 & .059 & 18.7 & \multirow{4}{*}{2} & $\begin{array}{l}0-5 \\
5-10\end{array}$ & $\begin{array}{l}\mathrm{A} 1 \\
\mathrm{~B} 21\end{array}$ & $\begin{array}{l}6.9 \\
72\end{array}$ & $\begin{array}{l}2.91 \\
1.95\end{array}$ & $\begin{array}{l}.118 \\
080\end{array}$ & 16.8 \\
\hline & $2-11$ & B21 & 8.0 & 2.50 & .134 & 29.4 & & $10-30$ & $\begin{array}{l}\text { B21 } \\
\text { B22 }\end{array}$ & $\begin{array}{l}1.2 \\
8.1\end{array}$ & $\begin{array}{l}1.95 \\
1.10\end{array}$ & $\begin{array}{l}.080 \\
.054\end{array}$ & $\begin{array}{l}17.8 \\
20.3\end{array}$ \\
\hline & $11-22$ & B22 & 8.5 & 1.45 & .116 & 31.9 & & $30-40$ & $\mathrm{~B} 3 \mathrm{ca}$ & 8.4 & 1.10 & .050 & 22.8 \\
\hline & $22-44$ & B3 & 8.2 & .83 & .089 & 31.9 & & & & & & & \\
\hline \multirow[t]{4}{*}{3} & $0-1$ & A & 6.6 & 7.19 & .065 & 16.5 & \multirow[t]{4}{*}{3} & $\begin{array}{l}0-8 \\
8-25\end{array}$ & $\begin{array}{l}A \\
B 2\end{array}$ & $\begin{array}{l}7.4 \\
8.0\end{array}$ & 1.17 & $.065^{\circ}$ & 14.6 \\
\hline & $1-12$ & B21 & 7.6 & 2.14 & .225 & 28.1 & & $\begin{array}{r}0-23 \\
25-34\end{array}$ & B2 & $\begin{array}{l}8.0 \\
8.5\end{array}$ & $\begin{array}{r}1.01 \\
82\end{array}$ & .059 & 21.5 \\
\hline & $12-26$ & B22 & 8.7 & 1.38 & .078 & 20.9 & & & & 0.2 & .82 & .050 & 20.9 \\
\hline & $26-40$ & B3 & 8.7 & .96 & .061 & 33.5 & & & & & & & \\
\hline
\end{tabular}

'Depths of layers from the original surface negative numbers indicate soil from furrow piled on the surface to form a ridge.

very low. Soils at Area 5 are much finer textured than those at Area 3 , where compaction and surface soil crusting and sealing are less likely to occur.

\section{Literature Cited}

Aldon, E.F., and G. Garcia. 1972. Vegetation changes as the result of soil ripping on the Rio Puerco in New Mexico. J. Range Manage. 25:381383.

Beetle, A.A. 1970. Recommended plant names. Wyoming Agr. Exp. Sta. Res. J. 31.

Branson, F.A., R.F. Miller, and I.S. McQueen. 1966. Contour furrowing, pitting and ripping on rangelands of the Western United States. J. Range Manage. 19:183-190.

Bresler, E. 1975. Two-dimensional transport of solutes during nonstead infiltration from a trickle source. Soil Sci. Soc. Amer. Proc. 39:604-613.

Hickey, W.C., Jr., and E.J. Dortignac. 1964. An evaluation of soil ripping and soil pitting on runoff and erosion in the semiarid Southwest. Inter- natl. Union Geodesy and and Geophys., Internat. Ass. Sci. Hydrol., Land Erosion, Precipitation, Hydrometry, Soil Moisture Comm. Pub. 65:22-23.

Jackson, M.L. 1958. Soil Chemical Analysis. Prentice-Hall Inc., Englewood Cliffs, N.J.

Richards, L.A. 1954. Saline and alkali soils. U.S. Dep. Agr. Agr. Handbook No. 60 .

Waller, S.S., J.K. Lewis, M.A. Brown, T.W. Heintz, R.E. Butterfield, and F.R. Gartner. 1978. Use of $35-\mathrm{mm}$ aerial photography in vegetation sampling. Proc. First Internat. Rangeland Cong., Aug. 1978, Denver, Colo. p. 48-49.

White, E.M. 1964. Morphological-chemical relationships of some thin-Ahorizon solidozed soils derived from moderately fine material on a well-drained slope. Soil Sci. 98:256-263.

White, E.M., and J.K. Lewis. 1969. Ecological effect of a clay soil's structure on some native grass roots. J. Range Manage. 22:401-404.

Wight, J.R., E.L. Neff, and R.L. Soiseth. 1978. Vegetation response to contour furrowing. J. Range Manage. 31:97-101. 